\title{
Phytosociology of the herbaceous-subshrub layer of a rupestrian complex in Serra do Espinhaço, Brazil
}

\section{Paula Alves Oliveira ${ }^{1 *}$, Israel Marinho Pereira ${ }^{1}$, Maria Cristina Teixeira Braga Messias ${ }^{2}$, Marcio Leles Romarco de Oliveira ${ }^{1}$, André César Pinheiro ${ }^{1}$, Evandro Luiz Mendonça Machado ${ }^{1}$ and Junior Lacerda Alves de Oliveira ${ }^{1}$}

Received: June 6, 2017

Accepted: October 5, 2017

\begin{abstract}
Rupestrian complexes of the Serra do Espinhaço are recognized for their high degree of biodiversity and endemism. However, environmental impacts, particularly from mining, have degraded these environments. The purpose of this study was to describe the herbaceous-subshrub communities that occur in quartzitic (QRC) and ferruginous (FRC) rupestrian complexes in different seasons of the year, with regard to floristic similarity and phytosociological structure. Additionally, the study aimed to identify native species with potential use for the restoration of similar degraded areas. Vegetation was sampled from plots located in the municipality of Conceição do Mato Dentro, state of Minas Gerais. Five contiguous strata of $10 \times 50 \mathrm{~m}$ were demarcated in each environment, in which 12 plots of $2 \times 1 \mathrm{~m}\left(2 \mathrm{~m}^{2}\right)$ were randomly distributed, for a total of 60 plots (sample units) in each physiognomy. The studied communities exhibited few similarities and lower floristic diversity than other rupestrian complexes. Detrended correspondence analysis distinguished the communities of FRC from those of QRC. The species with the highest value of importance in FRC were Bulbostylis fimbriata and Centrosema brasilianum, while in QRC Echinolaena inflexa had the highest values, thus, making them eligible for restoration programs in similar environments.
\end{abstract}

Keywords: canga, Cerrado, ferruginous grasslands, restoration of degraded areas, rupestrian grasslands

\section{Introduction}

The Serra do Espinhaço (Espinhaço Mountain Range) is located in one of most floristically diverse regions in the world, especially when considering its rocky outcrop environments (Giulietti et al. 1997). Brazilian savannas on rocky outcrops are known as rupestrian grasslands (Joly 1970; Giulietti et al. 1997) or rupestrian complexes (Semir 1991). The latter term, "rupestrian complex", is more appropriate because it represents the physiognomic variation found in this ecosystem.
In general, rupestrian complexes develop above $900 \mathrm{~m}$ and are associated with geological types such as quartzite, sandstone and itabirite along the Serra do Espinhaço, with disjunct occurrences in other Brazilian mountains (Giulietti et al. 1997). These mountain ecosystems are very old and are considered a museum of ancient lineages, as well as a cradle of continuous diversification of endemic lineages (Silveira et al. 2016). The surprising species richness found in the rupestrian complex of Serra do Espinhaço is favored by the diversity of environments it comprises, with wide latitudinal and elevational variation, isolation and the

1 Departamento de Engenharia Florestal, Universidade Federal dos Vales do Jequitinhonha e Mucuri, Campus JK, MGT 367, KM 583, 5000, Alto da Jacuba, 39100-000, Diamantina, MG, Brazil

2 Departamento de Biodiversidade, Evolução e Meio Ambiente, Instituto de Ciências Exatas e Biológicas, Universidade Federal de Ouro Preto, 35400-000, Ouro Preto, MG, Brazil

* Corresponding author: oliveiraalvespaula@gmail.com 
influence of a variety of vegetation domains (Giulietti et al. 1997; Silveira et al. 2016).

In the state of Minas Gerais (MG), these ecosystems are among the most threatened and least studied (Jacobi et al. 2007; Jacobi \& Carmo 2008b). The quartzitic rupestrian complex $(\mathrm{QRC})$ of Serra do Espinhaço includes environments that are impacted by mineral and vegetal extraction (Rapini et al. 2008), which has led to the degradation of many of them. On the other hand, the ferruginous rupestrian complex (FRC), also known as canga vegetation, are degraded mainly by the extraction of ore, as they develop upond large natural iron deposits (Jacobi et al. 2007; Jacobi \& Carmo 2008a; Vincent \& Meguro 2008; Messias et al. 2013; Vasconcelos 2014).

Research on the ecology of these rocky environments is still incipient, especially regarding floristic studies. In addition, the few studies that have been do are largely limited to the Quadrilátero Ferrífero (Iron Quadrangle; Jacobi \& Carmo 2008a; Vincent \& Meguro 2008; Messias et al. 2011; 2012). Floristic studies are of great importance for the Serra do Espinhaço given the great beta diversity of its rupestrian complex (Neves et al. 2017). Studies of this nature, among other important aspects, permit a better understanding of the geographic distribution of species and the establishment of patterns of endemism, as well as the development of conservation and restoration strategies for degraded areas.

Knowledge of the native species of regions to be restored increases the probability of success in environmental restoration (Araújo et al. 2006). An efficient way of determining patterns of these native species is through phytosociological studies that address the phenomena that affect the dynamics of these communities (MuellerDombois \& Ellenberg 2002). The purpose of this study was to characterize the herbaceous-subshrub communities on a quartzitic rupestrian complex $(\mathrm{QRC})$ and a ferruginous rupestrian complex (FRC) during different seasons of the year, in terms of floristic similarity and phytosociological structure, as well as identify native species with potential use in the restoration of similar degraded areas.

\section{Materials and methods}

\section{Location and characterization of the study area}

Sampling of vegetation was carried out in two sites with a predominance of rupestrian complex (Fig. 1), and which belong to the Anglo American mining company headquartered in the municipality of Conceição do Mato Dentro, MG, on the eastern border of the Southern Espinhaço. The climate of the region is classified as subtropical humid Cwa in the Köppen climate classification (Alvares et al. 2013).

The Fazenda Água Limpa encompasses an area of 78.22 ha ranging from 890 to $945 \mathrm{~m}$ in elevation (between $18^{\circ} 56^{\prime} 11.65^{\prime \prime} \mathrm{S} 43^{\circ} 24^{\prime} 53.12^{\prime \prime} \mathrm{W}$ and $18^{\circ} 56^{\prime} 11.68^{\prime \prime} \mathrm{S}$ $\left.43^{\circ} 24^{\prime} 55.39^{\prime \prime} \mathrm{W}\right)$. The predominant vegetation is the ferruginous rupestrian complex (FRC) with a herbaceousshrub habit with a substrate of canga couraçada. Even though marked variation is not evident within the sampled area of this site, the rupestrian complex exhiibits many physiognomic changes, mainly characterized by variation in the substrate.

The Fazenda Boa Esperança encompasses an area of 191.46 ha ranging from 740 to $800 \mathrm{~m}$ in elevation (between $18^{\circ} 55^{\prime} 26.57^{\prime \prime S} 43^{\circ} 28^{\prime} 40.35^{\prime \prime} \mathrm{W}$ and $18^{\circ} 55^{\prime} 28.18^{\prime \prime} \mathrm{S}$ $43^{\circ} 28^{\prime} 38.64^{\prime \prime} \mathrm{W}$ ). The predominant vegetation of this site is the quartzitic rupestrian complex $(\mathrm{QRC})$, with some patches of seasonal semideciduous forest and areas of pasture. Although it is a quartzitic rupestrian complex, it does not possess many rocky outcrops, but rather has a stony substrate.

In both locations, the soils are shallow, sandy and with low water retention. The two areas are separated from each other by approximately seven kilometers (straight line).

\section{Sampling}

Sixty sample plots (sampling units) of $2 \times 1 \mathrm{~m}\left(2 \mathrm{~m}^{2}\right)$ were randomly distributed in each site. In order to facilitate the distribution of the plots, five adjacent strata of $10 \times$ $50 \mathrm{~m}$ containing 12 plots each were allocated in each site, following an adaptation of the methodology used by Jacobi et al. (2008). This delimitation of the sample universe also had the objectives of demarcating an area representative of the studied physiognomy and avoiding the sampling of species of surrounding physiognomies.

All species were identified and vouchers deposited in the Herbário Dendrológico Jeanine Felfili (HDJF) of the Universidade Federal dos Vales do Jequitinhonha e Mucuri (UFVJM). Identification was performed using published literature, expert consultations and comparisons with virtual herbarium exsiccatae. The botanical family circumscription followed the Angiosperm Phylogeny Group IV system (APG IV 2016) and the spelling of names was verified with the Flora do Brasil 2020 database (under construction http:// floradobrasil.jbrj.gov.br/).

Density, frequency and coverage of all herbaceoussubshrub species were estimated. Visual estimation of species coverage was performed in a manner similar to the Braun-Blanquet method (Mueller-Dombois \& Ellenberg 2002). However, the estimated values were considered to represent a continuous variable, similarly to the method adopted by Messias et al. (2012), rather than being categorized by ranges of coverage and abundance as with the Braun-Blanquet method. In the case of species with clonal reproduction (orchids, grasses, among others), each isolated clump was considered as an individual. Sampling was performed during two periods of the year with the purpose of determining the behavior of the species regarding 

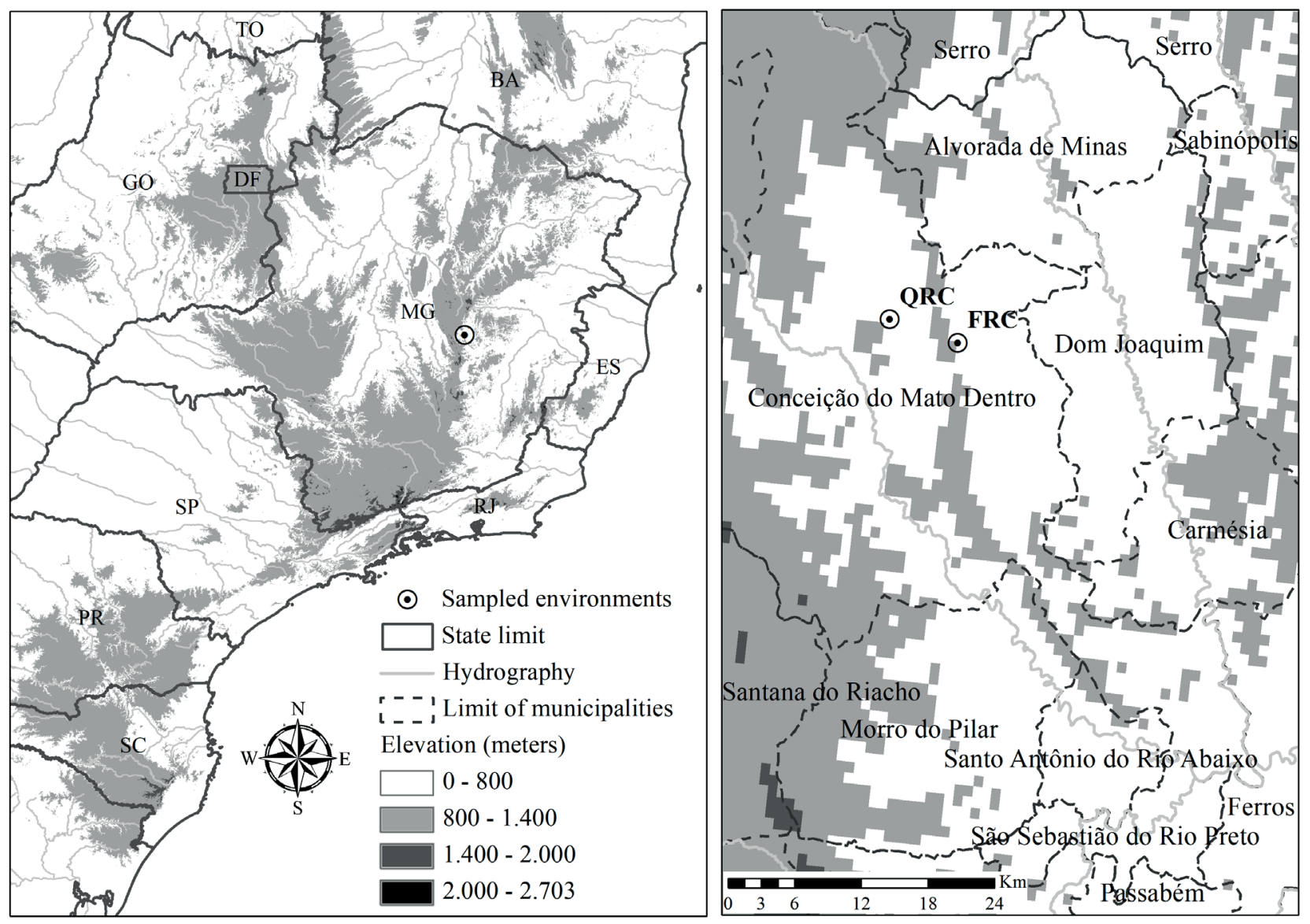

Figure 1. Geographic location of the study areas: $Q R C=$ quartzitic rupestrian complex and FRC = ferruginous rupestrian complex.

occurrence and coverage in the different seasons: one at the end of the wet season (February 2014) and another at the end of the dry season (October 2014).

\section{Data analysis}

The following phytosociological parameters were calculated by location and season according to MuellerDombois \& Ellenberg (2002): absolute density (AD), relative density $(\mathrm{RD})$, absolute frequency (AF), relative frequency $(\mathrm{RF})$, absolute coverage $(\mathrm{AC})$, relative coverage $(\mathrm{RC})$ and value of importance (VI). Floristic diversity was calculated using the Shannon diversity index (H') (Magurran 1988). The H' values obtained for each site and season were compared by the Hutcheson $t$-test, with a significance adjustment using the ranking technique of Bonferroni (Zar 2010), using the PAST software (Hammer et al. 2001).

The floristic similarity between sites was estimated by the Chao-Sørensen similarity index (Chao et al. 2005; 2006). A matrix with the species coverage and occurrence in each rupestrian complex typology (FRC, QRC) was used, correcting the estimation deviations that could be produced by similarity analyses based only on presence and absence (Chao et al. 2005; 2006). The Chao-Sørensen index was obtained using the EstimateS 8.0 program (Colwell 2006). The results were organized in a Venn diagram to aid visualization.

Detrended correspondence analysis (DCA) multivariate statistical technique was used to assess floristic relationships in the studied communities. The DCA is a non-parametric statistical technique that produces a sorting diagram in which the plots are distributed according to their similarity (Causton 1988). The DCA was performed on PC-ORD for Windows version 6.0 (Mccune \& Mefford 2011), using the presence and absence of species (qualitative variables), and FRC and QRC environments (categorical variables).

Indicator Species Analysis (ISA) (Dufrêne \& Legendre 1997), processed by PC-ORD for Windows version 6.0 (Mccune \& Mefford 2011), was employed to determine the occurrence of species in QRC and FRC environments, in each season of the year. This method combines information on the concentration of a species in a certain group of sample units (plots), and on the fidelity of the occurrence of the species to this same group. An indicator value (IV) is generated for each species in each group and the significance of the difference between the IV and a randomly generated value is determined by the Monte Carlo permutation test. Therefore, a species is only considered to be an indicator of 
Paula Alves Oliveira, Israel Marinho Pereira, Maria Cristina Teixeira Braga Messias, Marcio Leles Romarco de Oliveira, André César Pinheiro, Evandro Luiz Mendonça Machado and Junior Lacerda Alves de Oliveira

Table 1. Value of importance (\%) in wet season (VIW) and dry season (VID), values of herbaceous-subshrub species in areas of quartzite rupestrian complex (QRC) and ferruginous rupestrian complex (FRC) in Conceição do Mato Dentro, MG, Brazil.

\begin{tabular}{|c|c|c|c|c|}
\hline \multirow{2}{*}{ FAMILY/Species } & \multicolumn{2}{|c|}{ FRC } & \multicolumn{2}{|c|}{ RRC } \\
\hline & VIW & VID & VIW & VID \\
\hline \multicolumn{5}{|l|}{ ASTERACEAE } \\
\hline Acritopappus longifolius (Gardner) R.M. King \& H. Rob. & 0.48 & 0.7 & 3.8 & 3.89 \\
\hline Lepidaploa lilacina (Mart. ex DC.) H.Rob. & - & - & 2.51 & 2.53 \\
\hline Lepidaploa rufogrisea (A. St.-Hil.) H. Rob. & 0.25 & - & 0.14 & 0.15 \\
\hline Porophyllum angustissimum Gardner & 7.83 & 4.93 & 0.11 & 0.11 \\
\hline Symphyopappus brasiliensis (Gardner) R.M.King \& H.Rob. & - & - & 0.86 & 0.74 \\
\hline \multicolumn{5}{|l|}{ CACTACEAE } \\
\hline Pilosocereus aurisetus (Werderm.) Byles \& G.D. Rowley & 4.61 & 6.42 & - & - \\
\hline \multicolumn{5}{|l|}{ CYPERACEAE } \\
\hline Bulbostylis fimbriata (Nees) C.B. Clarke & 34.13 & 21.24 & - & - \\
\hline Bulbostylis sp. & - & - & 0.44 & 0.45 \\
\hline Lagenocarpus rigidus Nees & - & - & 3.63 & 3.52 \\
\hline \multicolumn{5}{|l|}{ ERIOCAULACEAE } \\
\hline Paepalanthus pedunculatus (Bong.) Ruhland & - & - & 5.08 & 4.58 \\
\hline Syngonanthus sp.1 & - & - & 0.21 & 0.11 \\
\hline Syngonanthus sp.2 & - & - & 0.13 & 0.13 \\
\hline \multicolumn{5}{|l|}{ EUPHORBIACEAE } \\
\hline Croton erythroxyloides Baill. & 5.43 & 7.23 & - & - \\
\hline Microstachys corniculata (Vahl) Griseb. & 8 & 8.5 & 2.03 & 2.03 \\
\hline \multicolumn{5}{|l|}{ FABACEAE } \\
\hline Aeschynomene elegans Schltdl. \& Cham. & 0.52 & 0.35 & - & - \\
\hline Centrosema brasilianum (L.) Benth. & 15.8 & 22.3 & - & - \\
\hline Galactia martii DC. & 2.42 & 2.65 & - & - \\
\hline Periandra mediterranea (Vell.) Taub. & - & - & 1.74 & 1.85 \\
\hline \multicolumn{5}{|l|}{ IRIDACEAE } \\
\hline Trimezia cathartica (Klatt) Niederl. & - & - & 0.64 & 0.55 \\
\hline \multicolumn{5}{|l|}{ LAMIACEAE } \\
\hline Hyptis marrubioides Epling & - & - & 0.12 & 0.12 \\
\hline \multicolumn{5}{|l|}{ LOGANIACEAE } \\
\hline Spigelia spartioides Cham. & - & - & 0.56 & 0.76 \\
\hline \multicolumn{5}{|l|}{ LYTHRACEAE } \\
\hline Cuphea diosmifolia A. St.-Hil. & - & - & 3.58 & 3.37 \\
\hline \multicolumn{5}{|l|}{ MELASTOMATACEAE } \\
\hline Cambessedesia hilariana (Kunth) DC. & - & - & 0.35 & 0.36 \\
\hline Clidemia sp. & - & - & 0.48 & 0.48 \\
\hline Lavoisiera imbricata (Thunb.) DC. & - & - & 0.33 & 0.34 \\
\hline Marcetia taxifolia Triana & - & - & 6.72 & 6.36 \\
\hline Tibouchina heteromalla (D. Don) Cogn. & - & - & 1.55 & 1.81 \\
\hline Não identificada & - & - & 0.1 & 0.1 \\
\hline PHYLLANTHACEAE & & & & \\
\hline Phyllanthus klotzschianus Müll.Arg. & - & - & 0.78 & 0.57 \\
\hline PHYTOLACCACEAE & & & & \\
\hline Microtea paniculata Moq & 2.97 & 1.83 & - & - \\
\hline POACEAE & & & & \\
\hline Apochloa euprepes (Renvoize) Zuloaga \& Morrone & - & - & 3.88 & 4.14 \\
\hline Apochloa poliophylla (Renvoize \& Zuloaga) Zuloaga \& Morrone & - & - & 2.45 & 2.46 \\
\hline Aristida sp. & - & - & 11.13 & 11.27 \\
\hline Echinolaena inflexa (Poir.) Chase & - & - & 17.56 & 17.7 \\
\hline Melinis minutiflora P. Beauv. & 5.33 & 7.39 & - & - \\
\hline Schizachyrium sanguineum (Retz.) Alston & - & - & 9.7 & 9.91 \\
\hline Trachypogon spicatus (L.f.) Kuntze & - & - & 1.25 & 1.79 \\
\hline Trichanthecium cyanescens (Nees ex Trin.) Zuloaga \& Morrone & - & - & 2.11 & 1.65 \\
\hline RUBIACEAE & & & & \\
\hline Declieuxia fruticosa (Willd. ex Roem. \& Schult.) Kuntze & - & - & 0.13 & 0.13 \\
\hline DIOSCOREACEAE & & & & \\
\hline Dioscorea sp. & - & - & 0.72 & 0.59 \\
\hline VELLOZIACEAE & & & & \\
\hline Barbacenia sp. & - & - & 6.4 & 6.69 \\
\hline Vellozia minima Pohl & 9 & 12.77 & - & - \\
\hline Vellozia sp. & 3.23 & 3.68 & 0.32 & 0.32 \\
\hline XYRIDACEAE & & & & \\
\hline Xyris macrocephala Vahl & - & - & 2.23 & 2.29 \\
\hline Xyris minarum Seub. & - & - & 1.36 & 1.3 \\
\hline Xyris sp. & - & - & 4.91 & 4.84 \\
\hline
\end{tabular}


a habitat when its highest IV is for that habitat and when the result of the Monte Carlo test is significant.

\section{Results}

In total, 46 species from 17 botanical families were recorded: 13 species and 8 families in the ferruginous rupestrian complex, and 37 species and 15 families in the quartzitic rupestrian complex. The families with the highest number of species in the FRC were Fabaceae (3), Asteraceae (2) and Euphorbiaceae (2), and in the QRC, Poaceae (7), Asteraceae (6) and Melastomaceae (6).

In both seasons of the year, the species with the highest value of importance in the FRC were Bulbostylis fimbriata and Centrosema brasilianum, while in QRC Echinolaena inflexa had the highest IV (Tab. 1). Among the species sampled, Pilosocereus aurisetus is listed as an endangered species, while others are endemic to Minas Gerais, such as Vellozia minima.

The studied community exhibited low floristic diversity: in the QRC, $\mathrm{H}^{\prime}=1.49$ nats.ind ${ }^{-1}$ and $\mathrm{H}^{\prime}=1.92$ nats.ind $^{-1}$, and in the FRC, $H^{\prime}=2.30$ nats.ind $^{-1}$ and $H^{\prime}=2.70$ nats. ind $^{-1}$, in the wet and dry seasons, respectively. There were no significant differences between $H^{\prime}$ values according to Hutcheson $t$-test, neither between environments nor between seasons in the same environment (Fig. 2).

Only $6.5 \%$ of the species were shared by the two environments in the dry season, and $8.7 \%$ in the wet season (Fig. 2). Similarity was not compared between seasons since there was no significant variation in species composition/ coverage.

The DCA identified two significantly $(p=0.002)$ distinct environments, segregating the plots of FRC from $Q R C$, which formed two clearly distinct groups (Fig. 3). Only the DCA for the wet season data was presented because there was no difference in the groups formed in the different seasons.

Of the 46 species analyzed as potential indicator species (Tab. 2), 12 exhibited a significant preference for one of the environments in the wet season and 13 in the dry season. Of the 12 species analyzed in the rainy season, four were inclined to FRC and eight to QRC. Likewise, in the dry period, five were inclined to FRC and eight to QRC. However, some species were not suggestive during both periods.

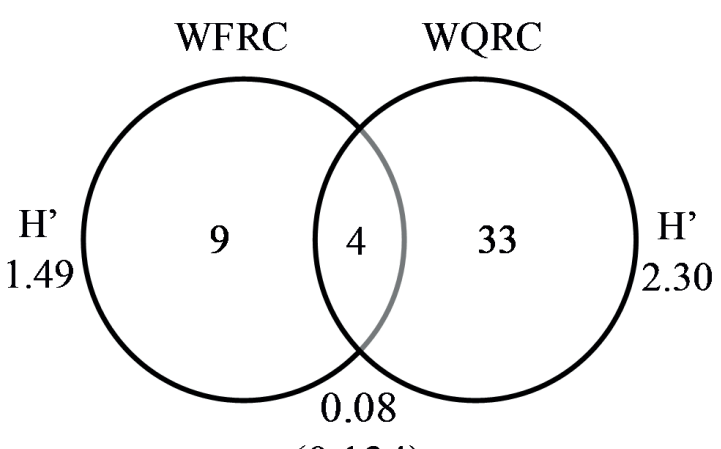

$(0.134)$

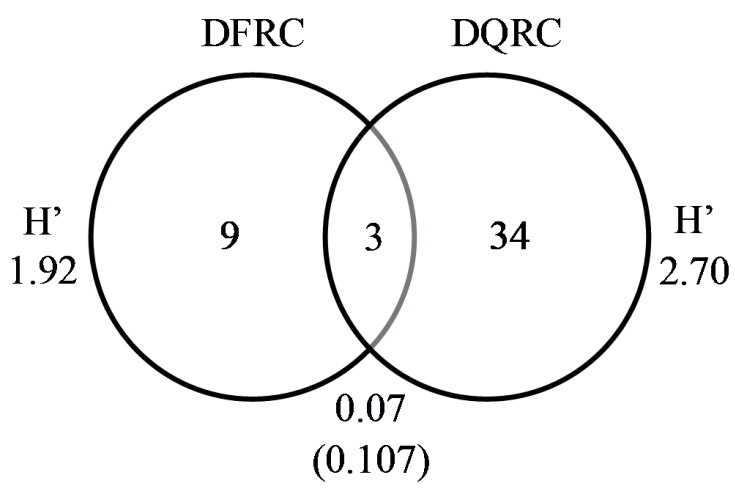

Figure 2. Venn diagram of the floristic composition of the different environments of the rupestrian complex of Conceição do Mato Dentro, Brazil, MG, showing the Shannon diversity index (H'), the number of unique and common species among the environments, and the Chao-Sørensen similarity index for the wet season (WFRC = ferruginous rupestrian complex and WQRC = quartzite rupestrian complex), and for the dry season (DFRC and DQRC). Values in parentheses are $p$ values from the Hutcheson $t$-test.

Table 2. Indicator species of the quartzite rupestrian complex (RRC) and ferruginous rupestrian complex (FRC) in the dry and wet season in Conceição do Mato Dentro, MG, Brazil. OIV = observed indicator value; EIV = expected indicator value; $S=$ standard deviation; $p=$ significance for the Monte Carlo test.

\begin{tabular}{|c|c|c|c|c|c|c|}
\hline \multirow{2}{*}{ Season } & \multirow{2}{*}{ Environment } & \multirow{2}{*}{ Species } & \multirow{2}{*}{ OIV } & \multicolumn{3}{|c|}{ EIV } \\
\hline & & & & Mean & $\mathbf{S}$ & $\mathbf{p}$ \\
\hline Wet & FRC & Porophyllum angustissimum & 39.60 & 14.10 & 2.89 & 0.0002 \\
\hline Wet & FRC & Pilosocereus aurisetus & 20.30 & 7.80 & 2.37 & 0.0006 \\
\hline Wet & QRC & Tibouchina heteromalla & 20.00 & 7.70 & 2.25 & 0.0004 \\
\hline Wet & FRC & Microtea paniculata & 18.60 & 7.20 & 2.16 & 0.0002 \\
\hline Wet & QRC & Trichanthecium cyanescens & 18.30 & 7.30 & 2.24 & 0.0004 \\
\hline Wet & QRC & Periandra mediterranea & 18.30 & 7.30 & 2.18 & 0.0004 \\
\hline Wet & QRC & Apochloa euprepes & 15.00 & 6.10 & 1.95 & 0.0042 \\
\hline
\end{tabular}


Paula Alves Oliveira, Israel Marinho Pereira, Maria Cristina Teixeira Braga Messias, Marcio Leles Romarco de Oliveira, André César Pinheiro, Evandro Luiz Mendonça Machado and Junior Lacerda Alves de Oliveira

Table 2. Cont.

\begin{tabular}{|c|c|c|c|c|c|c|}
\hline \multirow{2}{*}{ Season } & \multirow{2}{*}{ Environment } & \multirow{2}{*}{ Species } & \multirow{2}{*}{ OIV } & \multicolumn{3}{|c|}{ EIV } \\
\hline & & & & Mean & $\mathbf{s}$ & $\mathbf{p}$ \\
\hline Wet & QRC & Xyris minarum & 13.30 & 5.70 & 1.94 & 0.0062 \\
\hline Wet & FRC & Galactia martii & 11.90 & 5.20 & 1.88 & 0.0076 \\
\hline Wet & QRC & Xyris macrocephala & 11.70 & 5.10 & 1.83 & 0.0140 \\
\hline Wet & QRC & Smilax hilariana & 10.00 & 4.50 & 1.74 & 0.0278 \\
\hline Wet & $\mathrm{QRC}$ & Trimezia cathartica & 10.00 & 4.60 & 1.76 & 0.0290 \\
\hline Dry & QRC & Lepidaploa lilacina & 28.30 & 10.30 & 2.59 & 0.0002 \\
\hline Dry & QRC & Tibouchina heteromalla & 23.30 & 8.70 & 2.35 & 0.0002 \\
\hline Dry & FRC & Croton erythroxyloides & 22.00 & 8.20 & 2.31 & 0.0002 \\
\hline Dry & FRC & Pilosocereus aurisetus & 20.30 & 7.80 & 2.32 & 0.0004 \\
\hline Dry & QRC & Apochloa euprepes & 20.00 & 7.60 & 2.18 & 0.0006 \\
\hline Dry & QRC & Periandra mediterranea & 20.00 & 7.80 & 2.28 & 0.0008 \\
\hline Dry & FRC & Porophyllum angustissimum & 19.10 & 8.30 & 2.31 & 0.0006 \\
\hline Dry & QRC & Trichanthecium cyanescens & 13.30 & 5.70 & 1.95 & 0.0052 \\
\hline Dry & $\mathrm{QRC}$ & Xyris minarum & 13.30 & 5.70 & 1.90 & 0.0058 \\
\hline Dry & QRC & Spigelia spartioides & 11.70 & 5.20 & 1.92 & 0.0144 \\
\hline Dry & QRC & Xyris macrocephala & 11.70 & 5.20 & 1.81 & 0.0124 \\
\hline Dry & FRC & Galactia martii & 10.20 & 4.60 & 1.72 & 0.0120 \\
\hline Dry & FRC & Microtea paniculata & 8.50 & 4.10 & 1.63 & 0.0304 \\
\hline
\end{tabular}

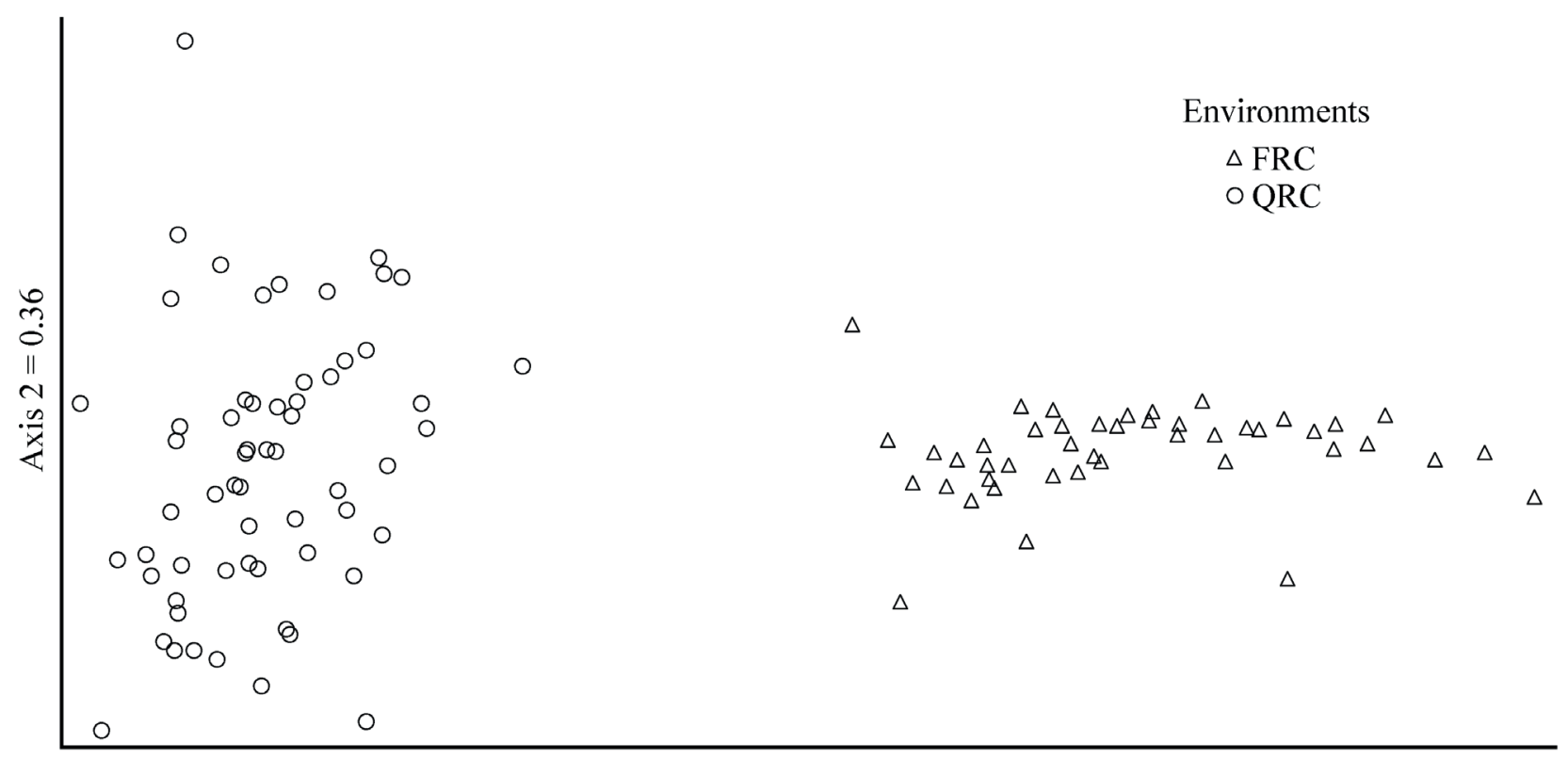

Axis $1=0.93$

Figure 3. Correlation map of the detrended correspondence analysis (DCA) of the floristic composition (presence and absence of species) for the ferruginous rupestrian complex (FRC) and quartzitic rupestrian complex (QRC) in Conceição do Mato Dentro, MG, Brazil.

\section{Discussion}

The families with the greatest richness in the studied rupestrian complexes were described as characteristic of the Serra do Espinhaço (Giulietti et al. 1997). Moreover, these families are similar to those found in floristic surveys of rupestrian complexes in the Quadrilátero Ferrífero (Brandão \& Gavilanes 1990; Brandão et al. 1991; Mourao \& Stehmann 2007; Viana \& Lombardi 2007; Jacobi et al. 2007), as well as in other areas along Serra do Espinhaço (Conceição \& Giulietti 2002; Conceição \& Pirani 2007; Alves \& Kolbek 2010).

In the ferruginous rupestrian complex, the species with higher VI were, in the wet season, $B$. fimbriata and, in the dry season, $C$. brasilianum. The coverage of $B$. fimbriata was observed to be very affected by the presence of water in the soil, suffering a drastic reduction in the dry season when compared to the others (64\%). Nevertheless, its potential use 
in the restoration of degraded areas in these environments cannot be ruled out since it has of clonal reproduction (Jacobi et al. 2008) that is able to rapidly recover aerial growth with the first rains and can efficiently colonize degraded areas by the reintroduction of rescued seedlings (Mello et al. 2014; Skirycz et al. 2014). Jacobi et al. (2008) previously recommended the use of this species in the restoration of areas degraded by iron mining because it is a species that can adapt to restricted environmental conditions and possesses higher VI in areas of ferruginous rupestrian complexes in the Quadrilátero Ferrífero.

Among the native grasses of the Cerrado, the specie with the highest VI in the present study, E. inflexa, had previously aroused interest for use in restoration programs of degraded areas in Brazil. However, some factors hamper the commercial use of the species, such as low fertility of $30 \%$ of the total seed produced (Aires et al. 2013) and seed dormancy (Figueiredo et al. 2012; Ramos et al. 2017). Nevertheless, planting of the species showed good performance in the revegetation of a gull colluvium in Ouro Preto, MG, with $100 \%$ survival, even in the absence of cultivation treatments (Marques et al. 2014), thus suggesting its potential for use in the restoration of similar environments.

Environments on rocky outcrops usually possess low floristic diversity compared to their surrounding ecosystems (Rizzini 1997; Jacobi et al. 2008; Neves et al. 2017). The diversity estimated by the Shannon index for the studied ferruginous rupestrian complex and quartzitic rupestrian complex were lower than that observed in other areas throughout Serra do Espinhaço. Although each site represents only one sample, which may explain the limited diversity observed, this diversity was still well below that found in the study by Jacobi et al. (2008) with the same sampling methodology.

In the Quadrilátero Ferrífero of Minas Gerais, a value of $\mathrm{H}^{\prime}=2.26$ nats. ind $^{-1}$ was reported for ferruginous outcrops in Ouro Preto, and $\mathrm{H}^{\prime}=2.94$ nats.ind $^{-1}$ in quartzitic outcrops in Mariana (Messias et al. 2012), both sampling 10 plots of 10 $\times 10 \mathrm{~m}$ at each site. In the Serra do Rola Moça State Park, an $\mathrm{H}^{\prime}=2.45$ nats.ind ${ }^{-1}$ was reported for a ferruginous outcrop (Jacobi et al. 2008), sampling 30 plots of $2 \times 1 \mathrm{~m}$, while $\mathrm{H}^{\prime}=2.79$ nats.ind ${ }^{-1}$ was reported for a quartzitic outcrop in Chapada Diamantina, Bahia (Conceição \& Giulietti 2002), sampling 80 plots of $2 \times 2 \mathrm{~m}$ at each site.

Rich biodiversity plays an important role in ecosystem functionality because of the redundancy of species that perform the same function in processes fundamental to the maintenance of biodiversity. Hence, if one species becomes locally extinct or experiences a population reduction, other species can perform its function, thus preserving the ecological functioning of the community. In the same way, environments that are less diverse are also less resilient because when a species is lost there is no redundancy to replace its function, and the environment becomes, more rapidly, at risk of collapse (Triantis et al.
2010). The low diversity found in the present study suggests special attention should be made to the conservation of these areas for the preservation of the ecological services these environments provide.

Some species belonging to the families Poaceae, Eriocaulaceae and Xyridaceae occurred exclusively in quartzitic outcrops, as has been reported by other studies as well (Viana \& Lombardi 2007; Messias et al. 2012; Carmo \& Jacobi 2013; Takahasi \& Meirelles 2014). According to Messias et al. (2011; 2013), the great abundance of species of Poaceae in quartzitic rupestrian complexes is related there ability to adapt to water deficit and seasonal flooding, as well as their ability to explore more superficial layers of the soil, which are richer in nutrients. On the other hand, according to the same authors, the higher cost of construction of aerial biomass in ferruginous rupestrian complexes favors the occurrence of perennial shrub species.

The limited similarity between the environments of the present study corroborates the existence of floristic differences conditioned by the nature of differing substrates, similar to what was reported by Vincent \& Meguro (2008), Messias et al. (2011; 2012; 2013), and Carmo \& Jacobi (2013). Thus, to contemplate the mosaic of communities encompassed by rupestrian complexes, several authors have suggested specifying the geological substrate in the terminology of rupestrian complexes in order to better portray them (Semir 1991; Vincent \& Meguro 2008).

Several studies have reported that, even among environments with the same type of geological substrate, floristic similarity is low due to geographic isolation (Giulietti et al. 1997; 2000; Burke 2003). For example, the similarity between two ferruginous rupestrian grasslands located in the Quadrilátero Ferrífero, one in Serra do Rola Moça and the other in Serra da Moeda, barely $32 \mathrm{~km}$ apart, was only $27 \%$ (Jacobi et al. 2007). In addition, four ferruginous rupestrian grasslands located in the Quadrilátero Ferrífero were found to share only $5 \%$ of their species (Jacobi \& Carmo 2008a).

This low similarity between the studied environments was evidenced by the DCA, which clearly separated the plots of FRC from those of QRC. The eigenvalue obtained for axis 1 of the ordering was high $(>0.5)$, which indicates that species substitution exists between its extremes (Braak 1995), that is between FRC and QRC environments. However, axis 2 of the DCA was short, with an eigenvalue $(<0.5)$ (Braak 1995), indicating that the floristic composition of plots within each environment were similar.

Floristic similarity may also be influenced by the distance between areas and their degree of isolation, which may repercute in the classification of species as indicators (Almeida \& Machado 2007). Thus, the high number of indicator species in each environment may have been a consequence of the low similarity between the environments and their floristic isolation demonstrated by the DCA.

The species with higher values of importance in the ferruginous rupestrian complex, Bulbostylis fimbriata and 


\section{Paula Alves Oliveira, Israel Marinho Pereira, Maria Cristina Teixeira Braga Messias, Marcio Leles Romarco de Oliveira, André César Pinheiro, Evandro Luiz Mendonça Machado and Junior Lacerda Alves de Oliveira}

Centrosema brasilianum, and in the quartzite rupestrian complex, Echinolaena inflexa, are here recommended for use in restoration programs in similar environments.

Since the process of mining causes great environmental impact to rupestrian complexes, leading to the loss of much of its vegetation coverage, it is essential to restore these degraded areas. In this way, the results presented here support the implementation of projects for vegetal recomposition using native species in order to mitigate environmental impacts and avoid the loss of biodiversity.

Considering the floristic richness and heterogeneity of the studied rupestrian complexes, and the presence of endemic and endangered species, their conservation is extremely important for the maintenance of their biodiversity, especially since the quartzitic rupestrian complex cannot be considered an area of compensation for the degradation of environments of the ferruginous rupestrian complex.

\section{Acknowledgements}

We acknowledge the Anglo American mining company for its logistical and financial support of the present study. This research was supported by a scholarship for scientific initiation from Fundação de Amparo à Pesquisa do Estado de Minas Gerais (FAPEMIG) and a masters scholarship from Universidade Federal dos Vales do Jequitinhonha e Mucuri (UFVJM) and Coordenação de Aperfeiçoamento de Pessoal de Nível Superior (CAPES).

\section{References}

Aires SS, Sato MN, Miranda HS. 2013. Seed characterization and direct sowing of native grass species as a management tool. Grass and Forage Science 69: 470-478.

Almeida HS, Machado ELM. 2007. Espécies Indicadoras do Componente Arbóreo em Comunidades de Floresta Estacional Decídua. Revista Brasileira de Biociências 5: 654-656.

Alvares CA, Stape JL, Sentelhas PC, Moraes GJL, Sparovek G. 2013. Köppen's climate classification map for Brazil. Meteorologische Zeitschrift 22: 711-728.

Alves R, Kolbek J. 2010. Vegetation strategy of Vellozia crinita (Velloziaceae). Biologia 65: 254-264.

APG IV - Angiosperm Phylogeny Group. 2016. An update of the Angiosperm Phylogeny Group classification for the orders and families of flowering plants: APG IV. Botanical Journal of the Linnean Society 181: 1-20.

Araújo FS, Martins SV, Meira-Neto JAA, Lani JL, Pires IE. 2006. Estrutura da vegetação arbustivo-arbórea colonizadora de uma área degradada por mineração de caulim, em Brás Pires, MG. Revista Árvore 30: 107-116.

Braak CJF. 1995. Ordination. In: Jongman RHG, Braak CJF, Tongeren OFR. (eds.) Data analysis in community and landscape ecology. Cambridge, Cambridge University Press. p. 91-173.

Brandão M, Gavilanes ML. 1990. Mais uma contribuição para o conhecimento da Cadeia do Espinhaço em Minas Gerais, Serra da Piedade - II. Daphne 1: 26-43.

Brandão M, Gavilanes ML, Laca-Buendia JP, Macedo JF, Cunha LHS. 1991. Contribuição para o conhecimento da Cadeia do Espinhaço em Minas Gerais (Serra de Itabirito) - III. Daphne 1: 39-41.
Burke A. 2003. Inselbergs in a changing world - global trends. Diversity and Distributions 9: 375-383.

Carmo FF, Jacobi CM. 2013. A vegetação de Canga no Quadrilátero Ferrífero, Minas Gerais: caracterização e contexto fitogeográfico. Rodriguésia 64: 527-541.

Causton DR. 1988. An introduction to vegetation analysis, principles and interpretation. London, Unwin Hyman.

Chao A, Chazdon RL, Colwell RK, Shen TJ. 2005. A new statistical approach for assessing similarity of species composition with incidence and abundance data. Ecology Letters 8: 148-159.

Chao A, Chazdon RL, Colwell RK, Shen TJ. 2006. Abundance-based similarity indices and their estimation when there are unseen species in samples. Biometrics 62: 361-371.

Colwell RK. 2006. Estimates: Statistical estimation of species richness and shared species from samples, Version 8.0. User's guide and application. http://viceroy.eeb.uconn.edu/estimates.

Conceição AA, Giulietti AM. 2002. Composição florística e aspectos estruturais de Campo Rupestre em dois platôs no Morro do Pai Inácio, Chapada Diamantina, Bahia, Brasil. Hoehnea 29: 37-48.

Conceição AA, Pirani JR. 2007. Diversidade em quatro áreas de campos rupestres na Chapada Diamantina, Bahia, Brasil: espécies distintas, mas riquezas similares. Rodriguésia 58: 193-206.

Dufrêne M, Legendre P. 1997. Species assemblages and indicator species: the need for flexible asymmetrical approach. Ecological Monographs 67: 345-366.

Figueiredo MA, Baêta HE, Kozovits AR. 2012. Germination of native grasses with potential application in the restoration of degraded areas in Quadrilátero Ferrífero, Brazil. Biota Neotropica 12: 118-123.

Flora do Brasil 2020 em construção. Rio de Janeiro. Jardim Botânico do Rio de Janeiro. http://floradobrasil.jbrj.gov.br.

Giulietti AM, Harley RM, Queiroz LP, Wanderley MGL, Pirani JR. 2000 Caracterização e endemismos nos campos rupestres da Cadeia do Espinhaço. In: Cavalcanti TB, Walter BMT. (orgs.) Tópicos atuais em botânica. 1st. edn. Brasília, SBB/CENARGEN. p. 311-318.

Giulietti AM, Pirani JR, Harley RM. 1997. Espinhaço Range Region, Eastern Brazil. In: Davis SD, Heywood VH, Herrera-Macbride O, Villa-Lobos J, Hamilton AC. (eds.) Centres of plant diversity. A guide and strategy for their conservation. The Americas. Cambridge, IUCN Publication Unity. p. 397-404.

Hammer Ø, Harper DAT, Ryan PD. 2001. PAST: Paleontological statistics software package for education and data analysis. Palaeontologia Electronica 4. http://palaeo-electronica.org/2001_1/past/issue1_01. htm. 15 Jan. 2015

Jacobi CM, Carmo FF. 2008a. Diversidade dos Campos rupestres Ferruginosos no Quadrilátero Ferrífero, MG. Megadiversidade 4: 24-32.

Jacobi CM, Carmo FF. 2008b. The contribution of ironstone outcrops to plant diversity in the Iron Quadrangle, a threatened Brazilian landscape. Ambio 37: 324-326.

Jacobi CM, Carmo FF, Vincent RC. 2008. Estudo fitossociológico de uma comunidade vegetal sobre canga como subsídio para a reabilitação de áreas mineradas no Quadrilátero Ferrífero, MG. Revista Árvore 32: $345-353$.

Jacobi CM, Carmo FF, Vincent RC, Stehmann JR. 2007. Plant communities on the ironstone outcrops - a diverse and endangered Brazilian ecosystem. Biodiversity and Conservation 16: 2185-2200.

Joly AB. 1970. Conheça a vegetação brasileira. São Paulo, Editora da Universidade de São Paulo.

Magurran AE. 1988. Ecological diversity and its measurement. Princeton, Princeton University Press.

Marques TED, Baêta MHE, Leite MGP, Martins SV, Kozovits AR. 2014 Crescimento de espécies nativas de cerrado e de Vetiveria zizanioides em processos de revegetação de voçorocas. Ciência Florestal 24: 843-856.

Mccune B, Mefford M. 2011. PC-ORD - Multivariate analysis of ecological data. Version 6.0. Gleneden Beach, MjM Software.

Mello L, Camargo R, Medeiros D, Almeida R, Vasconcelos R, Toledo F, Menini V. 2014. Partnerships and early planning with good science: the key to long-term ecological and socio-economic success. In: Zil V. (ed.) Proceedings of mine closure solutions. Ouro Preto, InfoMine. p. 26-30. 


\section{Phytosociology of the herbaceous-subshrub layer of a rupestrian complex in Serra do Espinhaço, Brazil}

Messias MCTB, Leite MGP, Meira-Neto JAA, Kozovits AR. 2011. Life-form spectra of quartzite and itabirite rocky outcrop sites, Minas Gerais, Brazil. Biota Neotropica 11: 255-268.

Messias MCTB, Leite MGP, Meira-Neto JAA, Kozovits AR. 2012. Fitossociologia de campos rupestres quartzíticos e ferruginosos no Quadrilátero Ferrífero, Minas Gerais. Acta Botanica Brasilica 26: 230-242.

Messias MCTB, Leite MGP, Meira-Neto JAA, Kozovits AR, Tavares R. 2013. Soil-vegetation relationship in Quartzitic and Ferruginous brazilian rocky outcrops. Folia Geobotanica 48: 509-521.

Mourão A, Stehmann J R. 2007. Levantamento da flora do Campo Rupestre sobre canga hematítica couraçada remanescente na mina do Brucutu, Barão de Cocais, Minas Gerais, Brasil. Rodriguésia 58: 775-786.

Mueller-Dombois D, Ellenberg H. 2002. Aims and methods of vegetation ecology. Caldwell, The Blackburn Press.

Neves DM, Dexter KG, Pennington RT, Bueno ML, Miranda PL, OliveiraFilho AT. 2017. Lack of floristic identity in campos rupestres-A hyperdiverse mosaic of rocky montane savannas in South America. Flora (in press). doi: 10.1016/j.flora.2017.03.011.

Ramos DM, Diniz P, Ooi MK, Borghetti F, Valls JF. 2017. Avoiding the dry season: dispersal time and syndrome mediate seed dormancy in grasses in Neotropical savanna and wet grasslands. Journal of Vegetation Science 28: 798-807.

Rapini AA, Ribeiro PL, Lamberti S, Pirani JR. 2008. A flora dos campos rupestres quartzíticos da Cadeia do Espinhaço. Megadiversidade 4: 16-24.
Rizzini CT. 1997. Tratado de fitogeografia do Brasil: aspectos ecológicos, sociológicos e florísticos. Rio de Janeiro, Âmbito Cultural.

Semir, J. 1991. Revisão taxonômica de Lychnophora Mart. (Vernoniaceae: Compositae). PhD Thesis, Universidade Estadual de Campinas, Campinas.

Silveira FA, Negreiros D, Barbosa NP, et al. 2016. Ecology and evolution of plant diversity in the endangered campo rupestre: a neglected conservation priority. Plant and Soil 403: 129-152.

Skirycz A, Castilho A, Chaparro C, Carvalho N, Tzotzos G, Siqueira JO. 2014. Canga biodiversity, a matter of mining. Frontiers in Plant Science 5: 653 .

Takahasi A, Meirelles ST. 2014. Ecologia da vegetação herbácea de bancadas lateríticas (cangas) em Corumbá, MS, Brasil. Hoehnea 41: 515-528.

Triantis KA, Borges PAV, Ladle RJ, et al. 2010. Extinction debt on oceanic islands. Ecography 33: 285-294.

Vasconcelos VV. 2014. Campos de altitude, campos rupestres e aplicação da lei da mata atlântica: estudo prospectivo para o estado de Minas Gerais. Boletim de Geografia 32: 110-133.

Viana PL, Lombardi JA. 2007. Florística e caracterização dos campos rupestres sobre canga na Serra da Calçada, Minas Gerais, Brasil. Rodriguésia 58: 159-177.

Vincent RC, Meguro M. 2008. Influence of soil properties on the abundance of plant species in ferruginous rocky soils vegetation, southeastern Brazil. Revista Brasileira de Botânica 31: 377-388.

Zar J. 2010. Biostatistical analysis. 5th. edn. Prentice Hall, Upper Saddle River. 